\title{
Anti-aging effects of Piper cambodianum P. Fourn. extract on normal human dermal fibroblast cells and a wound-healing model in mice
}

This article was published in the following Dove Press journal:

Clinical Interventions in Aging

29 July 2016

Number of times this article has been viewed

\section{Hyunji Lee' \\ Youngeun Hong' \\ So Hee Kwon ${ }^{2}$ \\ Jongsun Park' \\ Jisoo Park'}

'Department of Pharmacology and Medical Science, Metabolic Diseases and Cell Signaling Laboratory, Research Institute for Medical Sciences, College of Medicine, Chungnam National University, Daejeon, ${ }^{2}$ Department of Pharmacy, College of Pharmacy, Yonsei Institute of Pharmaceutical Sciences, Yonsei University, Incheon, South Korea
Correspondence: Jongsun Park; Jisoo Park Department of Pharmacology and Medical Science, Metabolic Diseases and Cell Signaling Laboratory, Research Institute for Medical Sciences, College of Medicine, Chungnam National University, Munwharo 266, Daejeon 350I5,

South Korea

Tel +82 $425808252 ;+8242580825$ I

Fax +82 425856627

Email insulin@cnu.ac.kr; base197@cnu.ac.kr
Background: Aging of skin is associated with environmental factors such as ultraviolet rays, air pollution, gravity, and genetic factors, all of which can lead to wrinkling of skin. Previous reports suggest that the wound repair is impaired by the aging process and strategies to manipulate the age-related wound healing are necessary in order to stimulate repair.

Objective: Several traditional plant extracts are well-known for their properties of skin protection and care. Piper cambodianum P. Fourn. $(P P F)$, a member of Piperacecae, is a plant found in Vietnam that might have therapeutic properties. Therefore, the effects of $P P F$ stem and leaf extract on aging process were investigated in vitro and in vivo.

Methods: $P P F$ extract dissolved in methanol was investigated using Western blotting, real-time quantitative reverse transcription-polymerase chain reaction, flow cytometry, and cell woundhealing assays. We assessed the anti-aging effect of $P P F$ in mouse using the wound-healing assay. The results were analyzed by Student's unpaired $t$-test; ${ }^{*} P<0.05$ and $* * P<0.01$ were considered to indicate significant and highly significant values, respectively, compared with corresponding controls.

Results: $P P F$ treatment demonstrated in vitro and in vivo anti-aging activity. Western blot analysis of $P P F$-treated normal human dermal fibroblast cells showed a dose-dependent increase in the expression of extracellular matrix genes such as collagen and elastin, but decreased expression of the aging gene matrix metalloproteinase-3. Quantitative polymerase chain reaction showed that $P P F$-treated cells displayed dose-dependent increase in messenger RNA expression levels of collagen, elastin, and hyaluronan synthase- 2 and decreased expression levels of matrix metalloproteinase- 1 aging gene. $P P F$ treatment led to decreased production of reactive oxygen species in cells subjected to ultraviolet irradiation. Furthermore, $P P F$ extract showed positive wound-healing effects in mice.

Conclusion: This study demonstrated the anti-aging and wound-healing effects of $P P F$ extract. Therefore, $P P F$ extract represents a promising new therapeutic agent for anti-aging and wound-healing treatments.

Keywords: $P P F$ extract, anti-aging, wound healing, antioxidant, ROS, normal human dermal fibroblasts

\section{Introduction}

Human skin consists of epidermal, dermal, and subcutaneous tissues. Epidermis is negatively affected by abiotic factors, ${ }^{1}$ and aging involves structural, functional, and biochemical changes. ${ }^{2}$ Aging of skin is associated with environmental factors such as ultraviolet (UV) rays, air pollution, gravity, and genetic factors, ${ }^{3}$ all of which can lead to wrinkling of skin., ${ }^{4,5}$ Reactive oxygen species (ROS), including superoxide anion 
radical $\left(\cdot \mathrm{O}_{2}-\right)$, hydrogen peroxide $\left(\mathrm{H}_{2} \mathrm{O}_{2}\right)$, hydroxyl radical $(\cdot \mathrm{OH})$, singlet oxygen $\left({ }^{1} \mathrm{O}_{2}\right)$, lipid peroxides $(\mathrm{LOOH})$, and their radicals (LOO-) are formed in skin exposed to UVA (320-400 nm) and UVB (290-320 nm). These factors induce skin aging, phototoxicity, inflammation, formation of malignant tumors, and breakdown of cell membranes. ${ }^{6-8}$ Several traditional plant extracts have well-known effects for skin protection and care. Piper cambodianum P. Fourn. (PPF), a member of Piperacecae, is a plant found in Vietnam that might have therapeutic properties, since Piper betle Linn., which belongs to same family, is used in variety of decoctions for curing wounds, burns, lymphangitis, and eczema. In addition, juice from the leaf of Kammaru, which is a variety of Piper betle, has the ability to heal pharyngitis, abdominal pain, and swelling. Its roots and fruits are well known for use in the treatment of malaria and asthma. ${ }^{9,10}$ The mechanistic action and pharmaceutical function of $P P F$ in skin protection has yet to be investigated in detail. This study investigated the potential anti-aging and wound-healing effects of $P P F$ stem and leaf extract in normal human dermal fibroblast (NHDF) cells and a mouse model of wound healing.

\section{Materials and methods Preparation of PFF extract}

PFF extract was provided by the Korea Research Institute of Bioscience \& Biotechnology (KRIBB). Dried powdered material was extracted in methylethanol $99.9 \%$ for 3 days with SD-Ultrasonic Cleaner (Seoul, South Korea) at $45^{\circ} \mathrm{C}$ for 72 hours. The extract was filtered and concentrated at $45^{\circ} \mathrm{C}$ (Rotary Evaporator, N-1000SWD-EYELA, Tokyo Rikakikai Co., Ltd., Bohemya, NY, USA), and dried at $70^{\circ} \mathrm{C}$ for 24 hours with Modul spin 40 (Biotron Corporation, Alberta, Canada). Extracted $P P F$ was diluted with pure water with different dose for each experiment.

\section{Antibodies and reagents}

The following antibodies were used: anti-elastin (Santa Cruz Biotechnology Inc., Dallas, TX, USA), anti-matrix metalloproteinase (MMP)-3 (Santa Cruz), anti-extracellular signal-regulated kinase (ERK) (Santa Cruz), anti-collagen (Abcam, Cambridge, UK), anti-actin (Sigma-Aldrich Co., St Louis, MO, USA), anti-tumor necrosis factor receptor (TNFR)-1 (Thermo Fisher Scientific, Waltham, MA, USA), anti-epidermal growth factor receptor (EGFR) (Thermo Fisher Scientific), anti-pp38 (Thr180/Tyr182; Cell Signaling Tech, Danvers, MA, USA), anti-c-Jun (Santa Cruz), anti-p53 (Cell Signaling Tech), and secondary antibodies (anti-mouse or anti-rabbit) from Komabiotech (Seoul, South Korea).

\section{Cell culture}

Normal Adult Human Primary Dermal Fibroblasts (NHDF) cells were purchased from ATCC (PCS-201-012, Manassas, VA, USA). NHDF cells were maintained in cultures in Dulbecco's Modified Eagle's Media (1:1) containing 10\% fetal bovine serum and $1 \%$ antibiotic. NHDF cells were grown at $37^{\circ} \mathrm{C}$ in humidified $5 \% \mathrm{CO}_{2}$.

\section{Analysis for cell viability}

NHDF cells were plated at a density of $1.0 \times 10^{4}$ cells/well in 96-well culture plates for complete attachment at $37^{\circ} \mathrm{C}$ with $5 \% \mathrm{CO}_{2}$ for 24 hours. The cells were then treated with $P P F$ at doses of 1,10 , and $50 \mu \mathrm{g} / \mathrm{mL}$ for 24 hours. The culture medium was then removed, followed by incubation with $90 \mathrm{~mL}$ of EXCyto (Lucigen Corporation, Middleton, WI, USA) $10 \mu \mathrm{L}$ at $37^{\circ} \mathrm{C}$ for 3 hours. The absorbency was measured at $450 \mathrm{~nm}$ (referenced $659 \mathrm{~nm}$ ) with an enzyme-linked immunosorbent assay reader (Bio-Rad Laboratories Inc., Hercules, CA, USA). The results were expressed as the relative cell viability of treated cells against those of the controls.

\section{Cell wound-healing assay (cell migration assay)}

For the cell migration assay, the monolayers were carefully scratched using a $10 \mu \mathrm{L}$ pipette tip. The cells were then treated with the $P P F$ at doses of 1,10 , and $50 \mathrm{mg} / \mathrm{mL}$ for 24 hours and then the wounded area was photographed.

\section{Analysis by real-time quantitative reverse transcription polymerase chain reaction}

Quantitative reverse transcription-polymerase chain reaction (qRT-PCR) analysis was performed as described previously. ${ }^{11,12}$ Total RNA was extracted from NHDF cell samples using the RNeasy kit (Qiagen NV, Venlo, the Netherlands). Complementary DNA was synthesized from total RNA with the SuperScript First-Strand Synthesis System (Thermo Fisher Scientific) and random hexamer primers. The real-time PCR measurement of individual complementary DNAs was performed using SYBR green dye to measure duplex DNA formation with the Thermo Fisher Scientific system (StepOne Plus) and normalized to the expression of glyceraldehyde 3-phosphate dehydrogenase. The primers and probes used in the real-time qRT-PCR are explained in Table 1.

\section{Western blot analysis}

The Western blot analysis was performed as described previously. ${ }^{13-15}$ NHDF cells were treated with $P P F$ extract for 24 hours, washed twice in ice-cold phosphate-buffered saline, and homogenized at $4{ }^{\circ} \mathrm{C}$ in 
Table I Primer set for real-time PCR

\begin{tabular}{|c|c|c|}
\hline Name & Primer & Sequence $\left(5^{\prime}-3^{\prime}\right)$ \\
\hline \multirow[t]{3}{*}{ Collagen } & $\mathrm{F}$ & TCC CCA GCC ACA AAG AGT \\
\hline & & CTA \\
\hline & $\mathrm{R}$ & TTT CCA CAC GTC TCG GTC A \\
\hline Matrix & $\mathrm{F}$ & CGA CTC TAG AAA CAC AAG \\
\hline \multirow[t]{3}{*}{ metalloproteinase-I } & & AGC AAG A \\
\hline & $\mathrm{R}$ & AAG GTT AGC TTA CTG TCA \\
\hline & & CAC GCT T \\
\hline \multirow[t]{2}{*}{ Elastin } & $\mathrm{F}$ & CTGCAAAGGCAGCCAAATAC \\
\hline & $\mathrm{R}$ & CACCAGGAACTAACCCAAACT \\
\hline Hyaluronan & $\mathrm{F}$ & GCT ACC AGT TTA TCC AAA \\
\hline \multirow[t]{3}{*}{ synthase-2 } & & CG \\
\hline & $\mathrm{R}$ & GGC TGT CAG AGC CTC GTG \\
\hline & & GCT TTG G \\
\hline Glyceraldehyde & $\mathrm{F}$ & TGA AGG TCG GAG TCA ACG \\
\hline 3-phosphate & & GAT TTG GT \\
\hline \multirow[t]{2}{*}{ dehydrogenase } & $\mathrm{R}$ & CAT GTG GGC CAT GAG GTC \\
\hline & & CAC CAC \\
\hline
\end{tabular}

Abbreviations: $F$, forward; R, reverse; $P C R$, polymerase chain reaction.

the lysis buffer containing $50 \mathrm{mM}$ Tris- $\mathrm{HCl}, \mathrm{pH} 7.5,1 \%$ Triton X-100, $300 \mathrm{mM} \mathrm{NaCl}, 0.1 \mathrm{mM}$ phenylmethylsulfonyl fluoride, $0.1 \mathrm{mM}$ sodium vanadate, $20 \mathrm{mM} \beta$-glycerol phosphate, $2 \mathrm{mM}$ dithiothreitol, $1 \mathrm{mM}$ leupeptin, and $10 \mathrm{mM} p$-nitrophenyl phosphate. Homogenates were centrifuged at $15,000 \times g$ for 10 minutes and supernatants were used for Western blot analysis. The protein concentration of lysates was measured by bovine serum albumin protein assay, and $50 \mu \mathrm{g}$ of the cell lysates was fractionated by $10 \%$ sodium dodecyl sulfate-polyacrylamide gel and blotted onto polyvinylidene difluoride membrane. After blocking with 5\% skim milk tris-buffered saline containing $0.02 \%$ Tween 20 , the membrane was probed with the relevant antibodies and visualized by enhanced chemiluminescence, according to the manufacturer's instructions (GE Healthcare, Pittsburgh, PA, USA). Actin was used for a loading control.

\section{ROS analysis}

NHDF cells were plated and incubated at a density of $1.0 \times 10^{6}$ cells $/$ well in six-well culture plates for 24 hours. The next day, the cells were UV irradiated at $40 \mathrm{~J}$ for 180 seconds with UV Crosslinker (Vilber Loirmat, Eberhardzell, Germany), nontreated and treated of PPF extracts for 24 hours. Cells were then washed and stained with $5 \mu \mathrm{M}$ CM-H ${ }_{2}$ DCFDA (Thermo fisher Scientific) in Hank's balanced salt solution, incubated at $37^{\circ} \mathrm{C}$ for 30 minutes. FACS Calibur flow cytometer (BD Biosciences, San Jose, CA, USA) was used for measuring $\mathrm{H}_{2} \mathrm{O}_{2}$ activity, using emission filter of $532 \mathrm{~nm}$. At least 10,000 cells were analyzed in each of the three independent experiments.

\section{Wound-healing treatments with mice}

C57Bl/6 male mice ( 7 weeks-old, $n=3$ ) from the Jungang Animal Company (Seoul, Korea) were first anesthetized, and the area assigned for wounding was shaved. Four $0.25 \mathrm{~cm}^{2}$ $(0.5 \times 0.5 \mathrm{~cm})$ excisional wounds were created on the dorsal skin (negative control and 1, 10,50 $\mu \mathrm{g} / \mathrm{mL} P P F$ extract). The treatment of wounded skin with PPF extracts was done with a cotton swab for 4 days (once a day). Mice were housed in standard mouse cages with a 12-hour light/dark cycle. The animal protocol in our study has been approved by the animal care and ethics committee of Chungnam National University. All animal-handling procedures were performed according to the Guide for the Care and Use of Laboratory Animals of the Korea National Institutes of Health and followed the guidelines of the Animal Welfare Act.

\section{Statistical analysis}

Quantification of Western blot analysis was carried out using the ImageJ program (NIH, Bethesda, MD, USA). Data are presented as mean \pm SD. The results were analyzed by Student's unpaired $t$-test (SPSS version 12.0 software, SPSS Inc., Chicago, IL, USA). ${ }^{*} P<0.05$ was considered significant, and $* * P<0.01$ was highly significant compared with corresponding control values.

\section{Results \\ Cell viability and wound-healing effects of PPF extract in NHDF cells}

$P P F$ was extracted from the leaf of Kammaru (Figure 1A). NHDF cells were treated with $P P F$ extract at doses of 1, 10, and $50 \mu \mathrm{g} / \mathrm{mL}$ for 24 hours. Cells treated with $P P F$ extract doses of 0,10 , and $50 \mu \mathrm{g} / \mathrm{mL}$ exhibited no effects on cell viability compared to untreated control cells (Figure 1B). In a cell wound-healing assay, confluent cell monolayers were injured by inflicting a scratch and then treated with $P P F$ extracts at concentrations from 1 to $50 \mu \mathrm{g} / \mathrm{mL}$ for 24 hours. The $P P F$-treated cells showed enhanced repair of the scratched area in a dose-dependent manner (Figure 1C and D).

\section{Enhanced extracellular matrix gene expression levels in PPF-treated NHDF cells}

Collagen is the major structural protein present in the extracellular space of various connective tissues in animals. ${ }^{16}$ Elastin is an elastic connective tissue protein that helps to maintain tissue shape after stretching or contracting by ensuring that tissues return to their original position. Hyaluronan or hyaluronic acid (HA) is a component of 
A

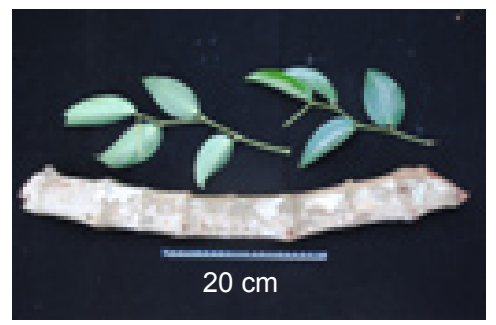

C

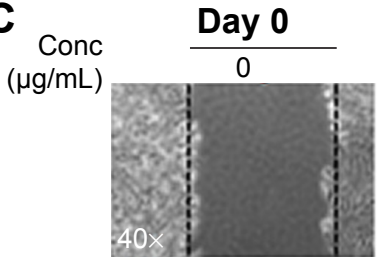

B

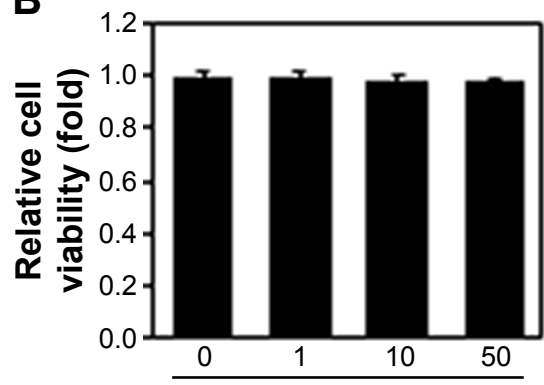

PPF extracts conc $(\mu \mathrm{g} / \mathrm{mL})$

Day 1

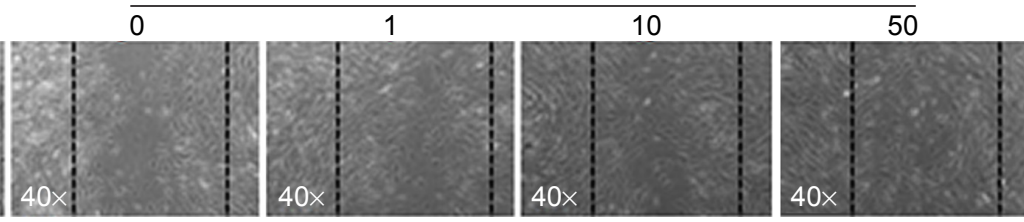

D

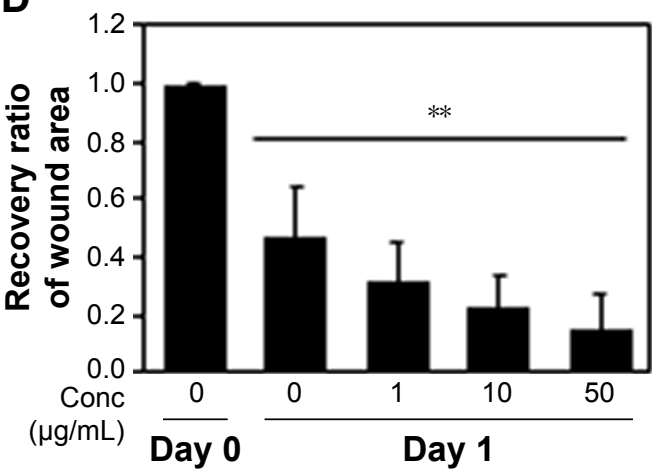

Figure I Cell viability and wound-healing assays.

Notes: PPF leaves and stem picture. (A) PPF extract applied at I and $10 \mu \mathrm{g} / \mathrm{mL}$ showed no cytotoxicity in the EXCyto assay using NHDF cells. (B) The cell wound-healing assay was imaged 24 hours after scratching the cell monolayer and treating with PPF extract at the indicated doses. (C) Once cells reached confluence, a single wound was made in the center of the monolayer using a $10 \mu \mathrm{l}$ pipette tip and the cells were treated with the indicated concentration of PPF extracts. After a 24 -hour incubation, a photograph was taken at $\times 10$ magnification under a microscope. (D) The photographic images from (C) in a dose-series were analyzed for gap area. The results are presented as the mean \pm standard deviation of three independent experiments. $* * P<0.0$ I.

Abbreviations: Conc, concentration; NHDF, normal human dermal fibroblast; PPF, Piper cambodianum P. Fourn.

the extracellular matrix (ECM) involved in lubricating joints and filling space through which cells can migrate. During wound healing and tissue repair, HA provides a framework for fibroblasts. HAS-2 is a newly identified hyaluronan synthase (HAS). After treatment with various doses of $P P F$ extract for 24 hours, ECM genes such as collagen, elastin, and HAS-2 expression levels were increased significantly in a dose-dependent manner. MMP-1 encoded by the $M M P 1$ gene in humans is known as an interstitial and fibroblast collagenase. ${ }^{16-18}$ MMPs are involved in the breakdown of ECM in normal physiological processes and tissue remodeling, and MMP-1 specifically breaks down the interstitial collagen types I, II, and III. We demonstrated that the messenger RNA level of MMP-1 was significantly decreased in $P P F$-treated cells in a dose-dependent manner (Figure 2).

\section{Enhanced ECM protein expression in PPF-treated NHDF cells}

Protein extracts of untreated or $P P F$-treated cells were analyzed by Western blot analysis. $P P F$-treated cells showed increased collagen and elastin protein levels compared with untreated controls (Figure 3). The ERK signaling pathway regulates type I collagen gene expression in human fibroblasts. ${ }^{17}$ Our data showed that protein levels of ERK were enhanced significantly, and the interstitial collagenase enzyme MMP-3 was downregulated significantly by $P P F$ extract in a dose-dependent manner (Figure 3). The messenger RNA levels of collagen and elastin were correlated with the changes in their protein levels. These results suggested that the anti-aging effects of $P P F$ on NHDF cells are related to the translational and transcriptional regulation of molecules involved in ECM. 

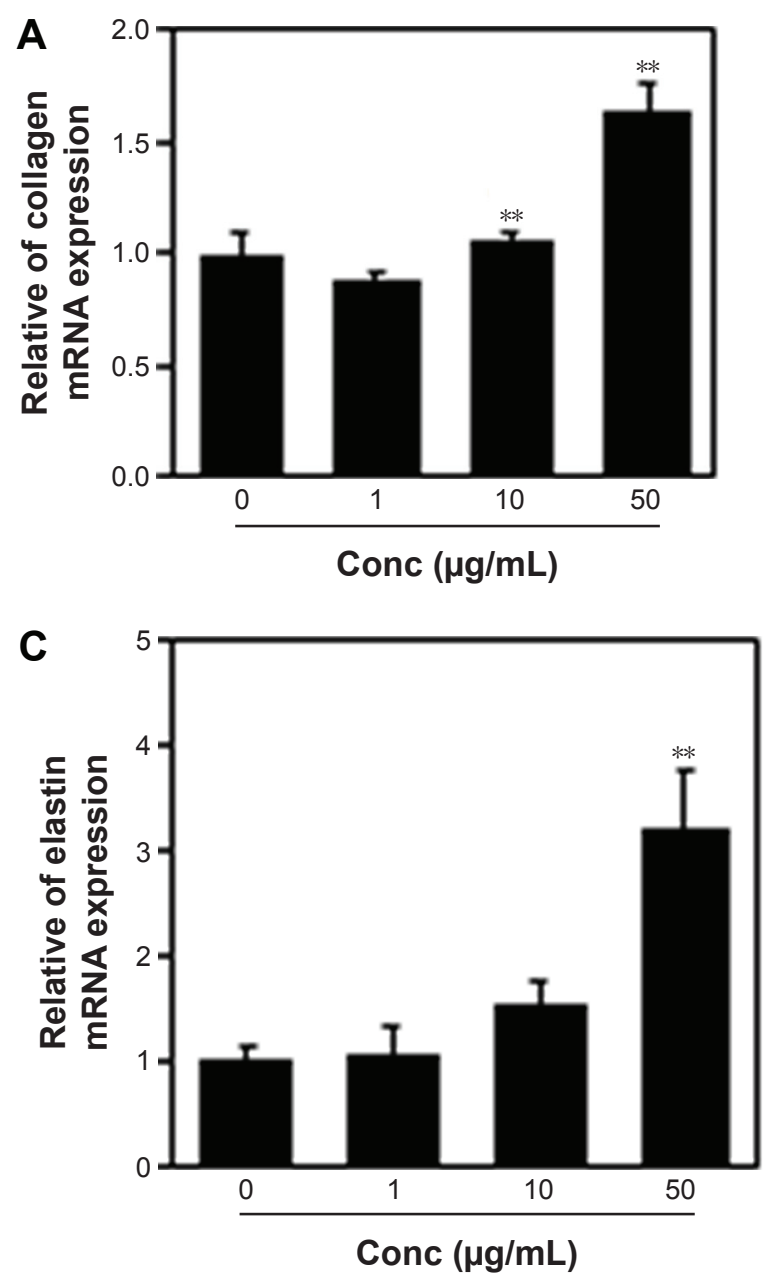
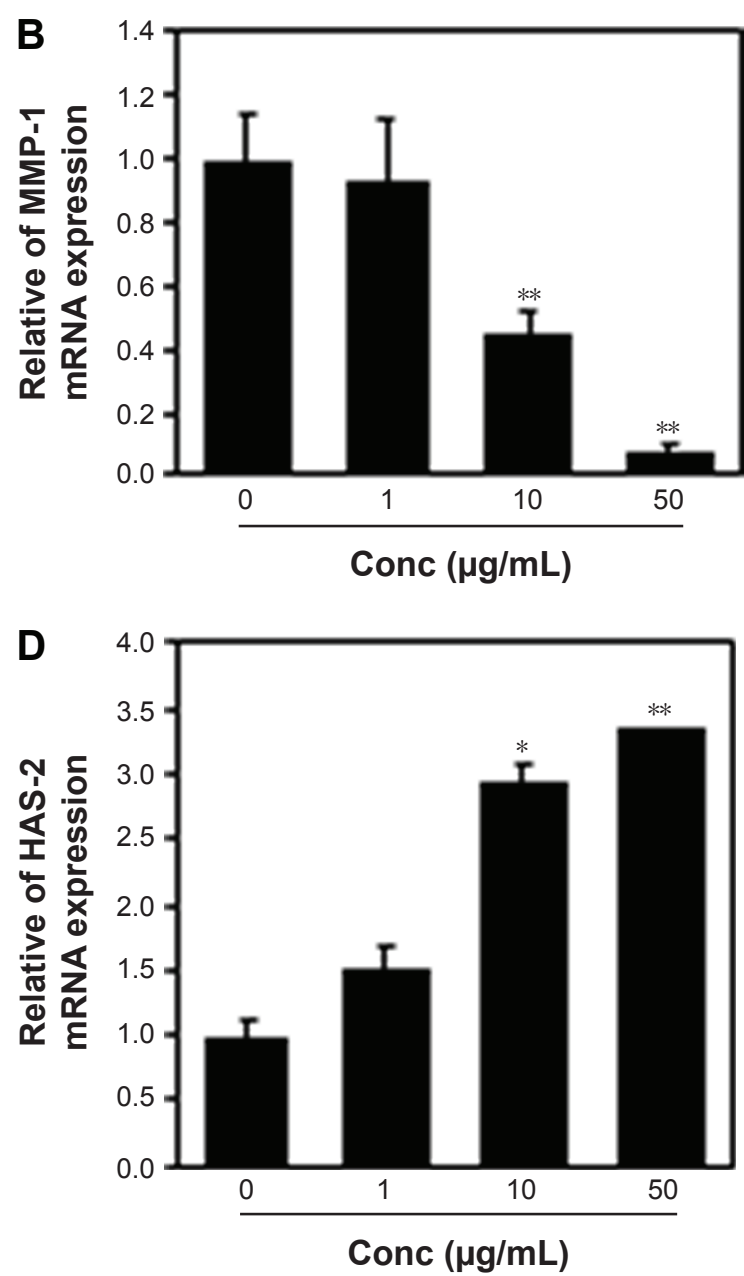

Figure 2 ECM gene expression level by q-PCR.

Notes: RNAs from untreated or PPF-treated cells were analyzed by real-time q-PCR with (A) collagen-, (B) elastin-, (C) hyaluronan synthase (HAS)-2, and (D) matrix metalloproteinase (MMP)-I-specific primers. The results are presented as the mean \pm SD of three independent experiments. $* P<0.05$, $* * P<0.0$ I.

Abbreviations: Conc, concentration; ECM, extracellular matrix; HAS, hyaluronan synthase; MMP, matrix metalloproteinase; mRNA, messenger RNA; NHDF, normal human dermal fibroblast; PPF, Piper cambodianum P. Fourn.; q-PCR, quantitative polymerase chain reaction; RNA, ribonucleic acid; SD, standard deviation.

\section{PPF extract protected NHDF cells from the effects of UV irradiation}

Skin cells respond quickly when exposed to UV or cytokines such as interleukin (IL)-4 and IL-13. ${ }^{19}$ Upon UV exposure, various factors are stimulated, including EGFR,,$^{20,21}$ TNFR, ${ }^{22}$ mitogen-activated protein (MAP) kinases, ERK, and c-Jun amino terminal kinase (JNK). ${ }^{23}$ Both JNK and p38 phosphorylate and activate the transcription factor c-Jun, which, in turn, elevates c-Fos and increases levels of transcription factor activator protein- $1,{ }^{24}$ which is required for transcription of MMPs. These receptors are activated by phosphorylation of MAP kinase and other downstream proteins. ${ }^{25}$ MAP kinases are activated by phosphorylation of specific threonine and tyrosine residues. ${ }^{24,26} \mathrm{UV}$ exposure leads to high expression of c-Jun and c-Fos heterodimers, numerous cytokines, and growth factors, which are phosphorylated by JNK and p38. ${ }^{27,28}$ Similarly, p53 protein levels were elevated, starting from 2.5 hours to 24 hours following UV-exposure. ${ }^{29} \mathrm{We}$ demonstrated that cells exposed to UV irradiation for 24 hours expressed TNFR1 and EGFR protein levels, which decreased in a dose-dependent manner when cells were treated with $P P F$. We examined the effect of UV radiation on both the phosphorylation and activity of p38 (Thr180/Tyr182). Protein levels of c-Jun and p53 were downregulated dramatically in $P P F$-treated cells (Figure 4A and B).

\section{PPF extract protected UV-irradiated NHDF cells from ROS}

UVB light stimulates the production of ROS,,$^{30,31}$ and UV exposure on the skin produces ROS such as $\mathrm{O}_{2}^{--}, \mathrm{H}_{2} \mathrm{O}_{2}$, and ${ }^{1} \mathrm{O}_{2}{ }^{32}$ Untreated and $P P F$-treated cells were subjected to UV irradiation for 24 hours, and the generation of ROS was measured by fluorescence-activated cell sorting (FACS). 

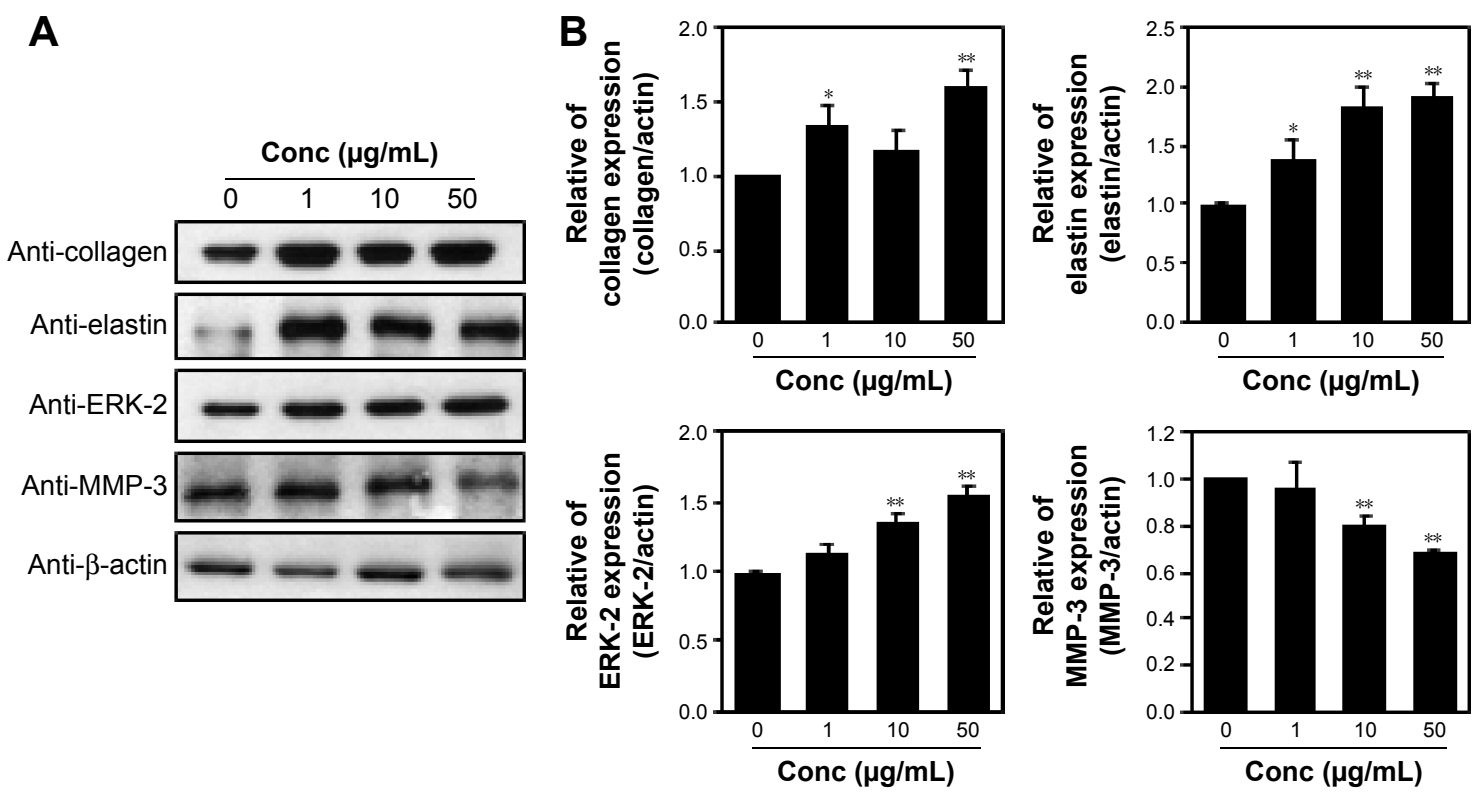

Figure 3 Regulation of ECM proteins in PPF-treated cells.

Notes: (A) NHDF cells were treated with PPF for 24 hours. Cell lysates were analyzed by immunoblotting using anti-collagen, anti-elastin, anti-MMP-3, and anti-ERK-2 antibodies. Results are representative of three independent experiments. (B) Actin, collagen, elastin, MMP-3, and ERK-2 in the immunoprecipitates were quantified by Western blotting. Bar heights are the respective mean \pm SDs of three independent experiments. $* P<0.05 ; * * P<0.01$.

Abbreviations: Conc, concentration; ECM, extracellular matrix; ERK, extracellular signal-regulated kinase; MMP, matrix metalloproteinase; NHDF, normal human dermal fibroblast; PPF, Piper cambodianum P. Fourn.; SDs, standard deviations.

A
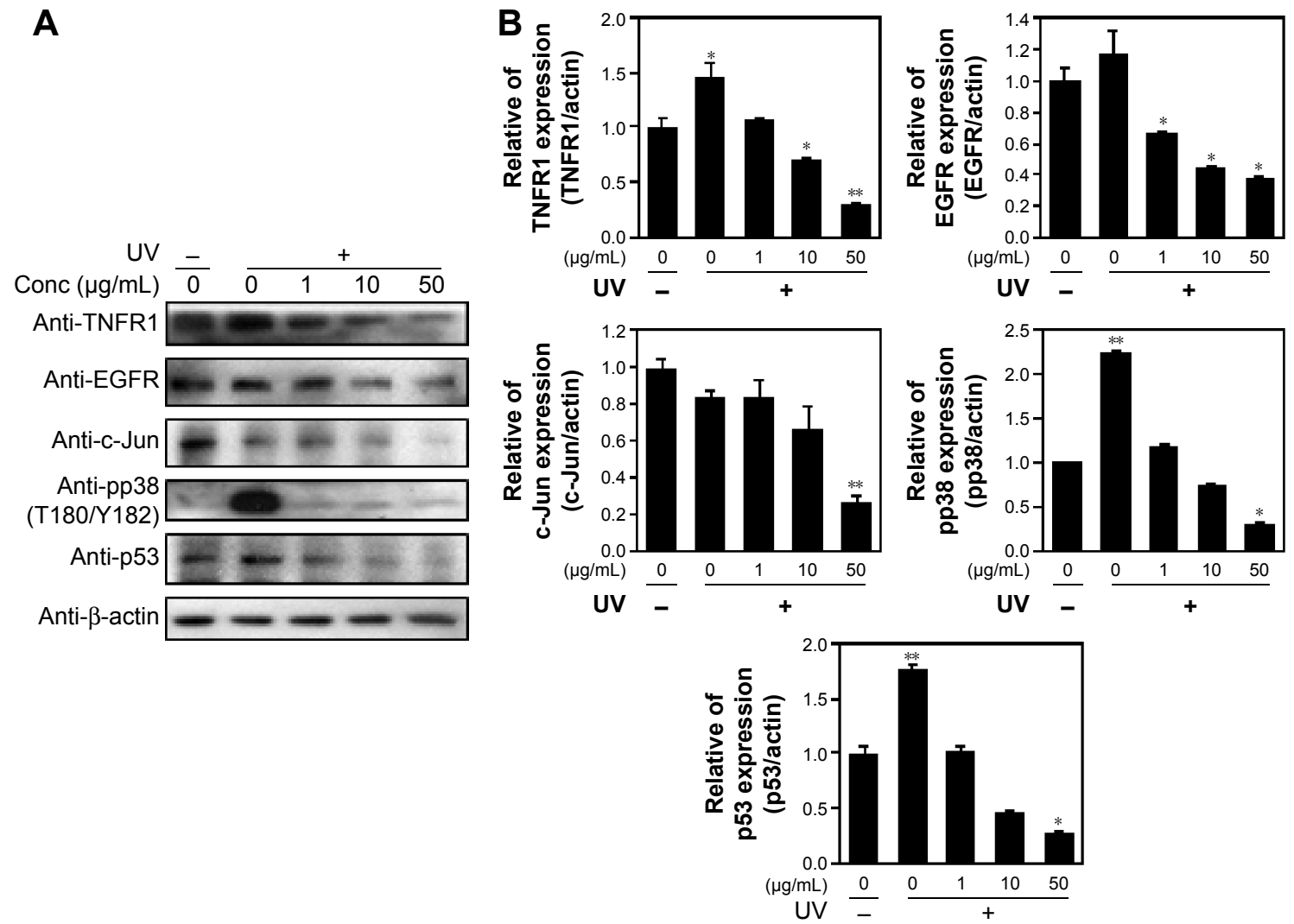

Figure 4 PPF extract inhibition of ROS production in UV-irradiated cells.

Notes: (A) NHDF cells were exposed to UV irradiation at $40 \mathrm{~J}$ for 180 seconds and treated with PPF for 24 hours. Cell lysates were analyzed by immunoblotting using anti-TNFR6, anti-c-Jun, anti-c-Fos, anti-pp38, or anti-p-JNK antibodies. Results are representative of three independent experiments. (B) Total and tyrosine-phosphorylated $\mathrm{p} 38$, JUK, actin, and TNFR6 in the immunoprecipitates were quantified by Western analyses. Bar heights are mean \pm SD of three independent experiments. $* P<0.05$; $* * P<0.01$.

Abbreviations: Conc, concentration; EGFR, epidermal growth factor receptor; JNK, c-Jun amino terminal kinase; JNK, c-Jun N-terminal kinase; NHDF, normal human dermal fibroblast; PPF, Piper cambodianum P. Fourn.; ROS, reactive oxygen species; SD, standard deviation; TNFR, tumor necrosis factor receptor; UV, ultraviolet. 
UV irradiation increased ROS production, while $P P F$ extract decreased ROS production in NHDF cells. The ROS levels of $\mathrm{H}_{2} \mathrm{O}_{2}$ were measured using the cell permeants $2^{\prime}, 7^{\prime}$-dichlorodihydrofluorescein diacetate (CM- $\left.\mathrm{H}_{2} \mathrm{DCFDA}\right)$ (Figure 5A). UV irradiation increased the ROS levels of $\mathrm{H}_{2} \mathrm{O}_{2}$, whereas ROS levels were reduced by $P P F$ extract in a dose-dependent manner (Figure 5B). These results indicated that $P P F$ extract protects dermal fibroblasts from UV irradiation by reducing ROS generation.

\section{Macroscopic observation of wound healing in mice}

Wounds were created on the backs of mice and then treated with $P P F$ extract $(0,1,10$, and $50 \mu \mathrm{g} / \mathrm{mL})$; the wound areas were measured each day for 4 days. On day 4 , the areas surrounding the wounds in $P P F$-treated mice showed decreased redness in a dose-dependent manner compared to untreated wound areas
(Figure 5). The extract-treated wound areas were smaller than the untreated wound area, showing a dose-dependent pattern. On day 4, the wound areas treated with $50 \mu \mathrm{g} / \mathrm{mL}$ of $P P F$ were completely covered by new epithelium. No wound areas were infected (Figure 6A and B). The ratios of wound areas on days 0 and 4 were calculated (Figure 6C).

\section{Discussion}

The use of herbal materials and different plant parts has been increasing with concomitant advances in phytotherapy. Herbal materials have been used in various forms such as mono- or polyherbal drugs, dietary supplements, and dietary ingredients, and many have become well-known and safe commercial commodities. ${ }^{33}$ Various plants, including $P P F$, have been investigated for their potential pharmacological properties, but no comparative study was performed previously with $P P F$ extract. This study was performed to determine
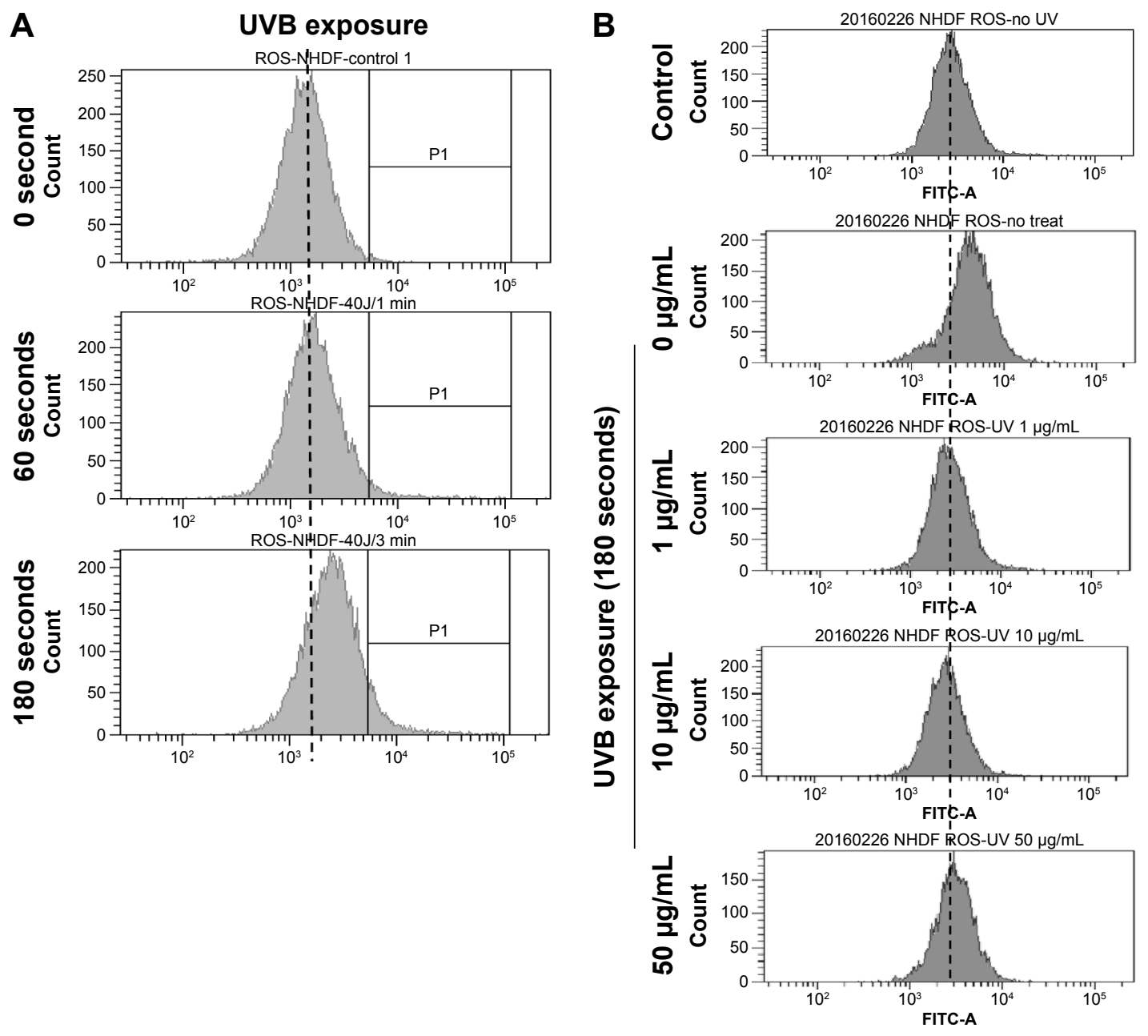

Figure 5 PPF-mediated inhibition of ROS production in UV-irradiated cells.

Notes: (A) Cells were treated with UVB irradiation (40 J) for the indicated time and then incubated with $2^{\prime}, 7^{\prime}$-dichlorodihydrofluorescein diacetate for 30 minutes. The generation of ROS was measured by FACS. (B) Cells were exposed to UVB (40 J) for 180 seconds and treated with the indicated concentration of PPF for 24 hours. ROS production were estimated with the staining of $2^{\prime}, 7^{\prime}$-dichlorodihydrofluorescein diacetate and analyzed by FACS.

Abbreviations: FACS, fluorescence-activated cell sorting; FITC, fluorescein isothiocyanate; NHDF, normal human dermal fibroblast; PPF, Piper cambodianum P. Fourn.; ROS, reactive oxygen species; UV, ultraviolet; UVB, ultraviolet $B$. 
A
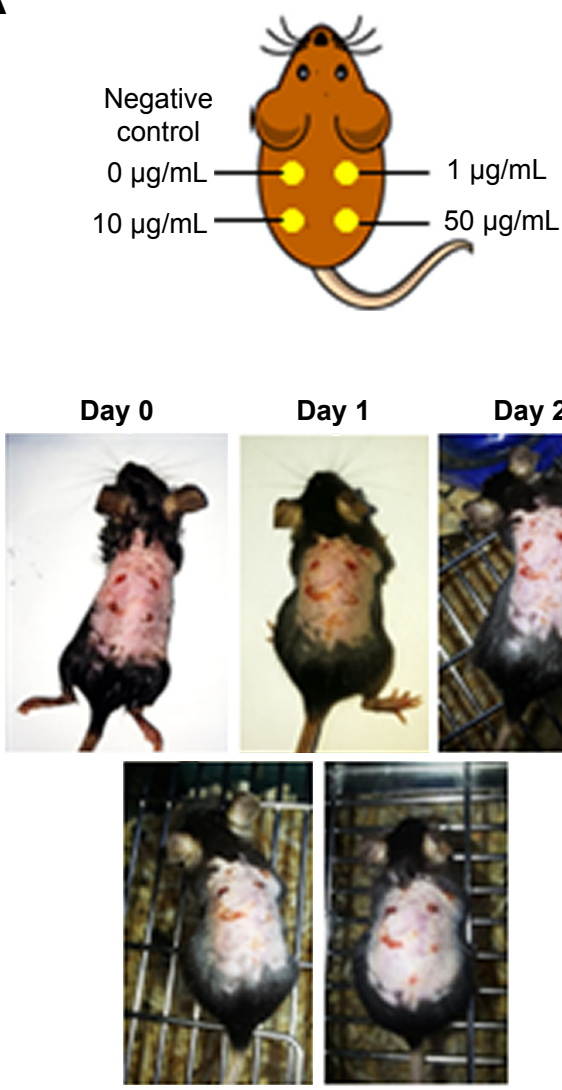

Day 3
Day 1
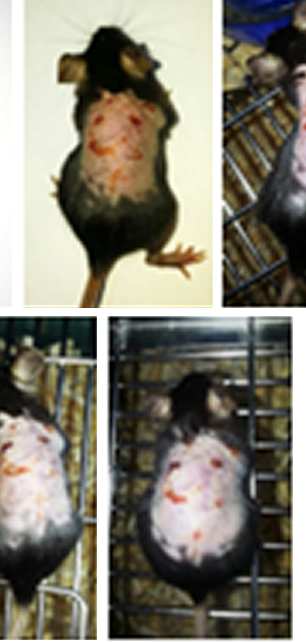

Day 4
B

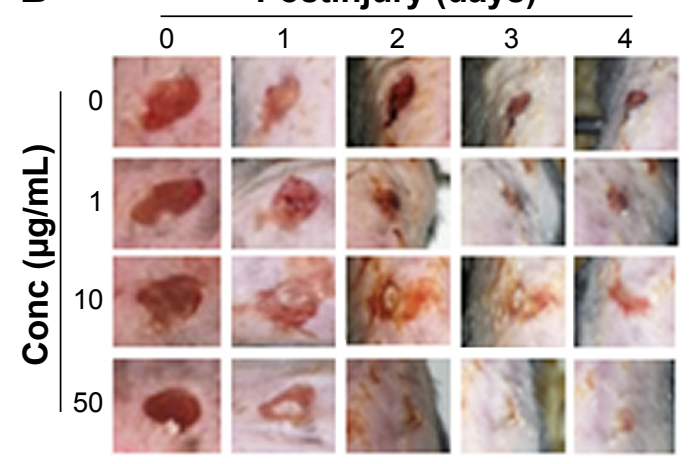

C

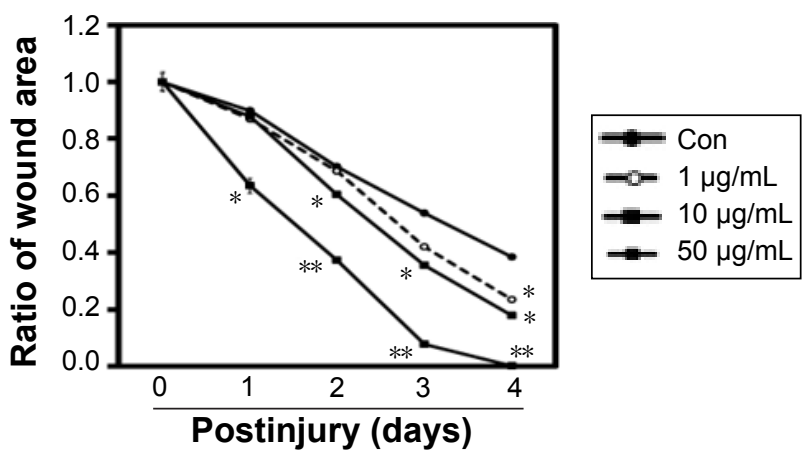

Figure 6 Wound healing effects on impaired mouse skin.

Notes: (A) Wounds of 5-mm diameter were created on the dorsal skin of 7-week-old male C57Bl/6 mice ( $\mathrm{n}=3$ ). The recovery of wounds was evaluated with PPF treatment in the different concentration (negative control and postwound treatment with PPF at $\mathrm{I}, 10$, and $50 \mu \mathrm{g} / \mathrm{mL}$ ). (B) The wound area was determined by measuring the diameter of the open wounds. (C) The wound area was calculated using the dimension of the open wounds; $* P<0.05 ; * * P<0.01$.

Abbreviations: PPF, Piper cambodianum P. Fourn; Conc, concentration.

the effects of $P P F$ extract on wound-healing activities using incision wound models in mice. Wound healing involves the re-establishment of tissue integrity through processes associated with inflammation, proliferation, and remodeling stages. ${ }^{34}$ The skin remodeling stage is characterized by the reformulation and reformation of collagen fiber components that improve tensile strength. ${ }^{35}$ The healing process is regulated mostly by the biosynthesis and deposition of new collagen and subsequent maturation. ${ }^{36}$ In our wound study, $P P F$ extract showed increased wound-healing effects compared with the control (Figures 1C and 6). Such healing might be due to the increased collagen concentration and stabilization of the fibers. In the tissue repair process, inflammatory cells enhance the migration and proliferation of endothelial cells, leading to neovascularization of connective tissue cells that synthesize extracellular matrices, including collagen and keratinocytes, resulting in the reepithelialization of wounded tissue. ${ }^{37}$ The faster wound contraction rate may increase the gap junctional intracellular communication in fibroblasts and enhance faster maturation of granulation tissue. ${ }^{38}$ In the incision wound model, mice treated with $P P F$ extract showed faster wound healing compared with controls (Figure 6). Numerous studies have revealed that downregulation of the p38 kinase pathway protects various wild-type p53-expressing cell lines from genotoxic stress. ${ }^{39,40}$ Our data showed that p38 expression in UV-irradiated cells was downregulated by $P P F$ treatment. Therefore, $P P F$ extract obtained from leaves and stems demonstrated effective treatment in wound healing. $P P F$ extract decreased ROS production from UV irradiation by scavenging ROS in NHDF cells (Figure 5A and B). Moreover, $P P F$ extract accelerated wound healing after skin irradiation ((Figure 6A-C). These results suggested that $P P F$ extract protects skin from UV irradiation damage, and might be useful as a novel raw material in cosmetic application.

\section{Conclusion}

This study investigated the potential anti-aging and woundhealing effects of PPF stem and leaf extract in NHDF cells 
and a mouse model of wound healing. The treatment of NHDF cells with PPF extracts promote the recovery of the scratched area in a dose-dependent manner as well as the enhancement of ECM gene expression. In addition, PPF extracts were able to protect the cell from UV exposure by reducing ROS production. Finally these observation are further evaluated and confirmed in the model mice for in-vivo wound-healing. Therefore, PPF extract represent a promising new therapeutic agent for anti-aging and wound-healing treatment.

\section{Acknowledgments}

This study was supported by the Basic Science Research Program through the National Research Foundation of Korea (NRF), funded by the Ministry of Education (NRF-2014R1A1A3050752). The authors would like to thank Korea Research Institute of Bioscience \& Biotechnology (KRIBB) for providing to $P P F$ extracts.

\section{Disclosure}

The authors report no conflicts of interest in this work.

\section{References}

1. Slominski AT, Zmijewski MA, Semak I, et al. Cytochromes p450 and skin cancer: role of local endocrine pathways. Anticancer Agents Med Chem. 2014;14(1):77-96.

2. Gilchrest BA. Skin aging and photoaging. Dermatol Nurs. 1990; 2(2):79-82.

3. Ha TY. Development of functional food materials for healthy life. Korean J Crop Sci. 2006;51:26-39.

4. Makrantonaki E, Zouboulis CC. Molecular mechanisms of skin aging: state of the art. Ann N Y Acad Sci. 2007;1119:40-50.

5. Seo MY, Chung SY, Choi WK, et al. Anti-aging effect of rice wine in cultured human fibroblasts and keratinocytes. J Biosci Bioeng. 2009; 107(3):266-271.

6. Kligman AM. Early destructive effect of sunlight on human skin. JAMA. 1969;210(13):2377-2380.

7. Oikarinen A, Karvonen J, Uitto J, Hannuksela M. Connective tissue alterations in skin exposed to natural and therapeutic UV-radiation. Photodermatol. 1985;2(1):15-26.

8. Bech-Thomsen N, Wulf HC. Carcinogenic and melanogenic effects of a filtered metal halide UVA source and a tubular fluorescent UVA tanning source with or without additional solar-simulated UV radiation in hairless mice. Photochem Photobiol. 1995;62(4):773-779.

9. De MS, Lahiri SC. Studies on leaves of Piper betle. Bull Calcutta Sch Trop Med. 1971;19(3):69-72.

10. Ferreres F, Oliveira AP, Gil-Izquierdo A, Valentão P, Andrade PB. Piper betle leaves: profiling phenolic compounds by HPLC/DAD-ESI/ MS(n) and anti-cholinesterase activity. Phytochem Anal. 2014;25(5): $453-460$

11. Na CH, Hong JH, Kim WS, et al. Identification of protein markers specific for papillary renal cell carcinoma using imaging mass spectrometry. Mol Cells. 2015;38(7):624-629.

12. Cheon JM, Kim DI, Kim KS. Insulin sensitivity improvement of fermented Korean Red Ginseng (Panax ginseng) mediated by insulin resistance hallmarks in old-aged ob/ob mice. J Ginseng Res. 2015;39(4):331-337.

13. Kim AY, Kwak JH, Je NK, Lee YH, Jung YS. Epithelial-mesenchymal transition is associated with acquired resistance to 5-fluorocuracil in HT-29 colon cancer cells. Toxicol Res. 2015;31(2):151-156.
14. Li Y, Park J, Piao L, et al. PKB-mediated PHF20 phosphorylation on Ser291 is required for 553 function in DNA damage. Cell Signal. 2013; 25(1):74-84.

15. Kim IS, Yang SY, Han JH, Jung SH, Park HS, Myung CS. Differential gene expression in GPR40-overexpressing pancreatic betacells treated with linoleic acid. Korean J Physiol Pharmacol. 2015; 19(2):141-149.

16. Di Lullo GA, Sweeney SM, Korkko J, Ala-Kokko L, San Antonio JD. Mapping the ligand-binding sites and disease-associated mutations on the most abundant protein in the human, type I collagen. $J$ Biol Chem. 2002;277(6):4223-4231.

17. Brinckerhoff CE, Ruby PL, Austin SD, Fini ME, White HD. Molecular cloning of human synovial cell collagenase and selection of a single gene from genomic DNA. J Clin Invest. 1987;79(2):542-546.

18. Pendas AM, Santamaría I, Alvarez MV, Pritchard M, LópezOtín C. Fine physical mapping of the human matrix metalloproteinase genes clustered on chromosome 11q22.3. Genomics. 1996;37(2): 266-268.

19. Bhogal RK, Bona CA. Regulatory effect of extracellular signal-regulated kinases (ERK) on type I collagen synthesis in human dermal fibroblasts stimulated by IL-4 and IL-13. Int Rev Immunol. 2008;27(6):472-496.

20. Sachsenmaier C, Radler-Pohl A, Zinck R, Nordheim A, Herrlich P, Rahmsdorf HJ. Involvement of growth factor receptors in the mammalian UVC response. Cell. 1994;78(6):963-972.

21. Warmuth I, Harth Y, Matsui MS, Wang N, DeLeo VA. Ultraviolet radiation induces phosphorylation of the epidermal growth factor receptor. Cancer Res. 1994;54(2):374-376.

22. Dy LC, Pei Y, Travers JB. Augmentation of ultraviolet B radiationinduced tumor necrosis factor production by the epidermal plateletactivating factor receptor. J Biol Chem. 1999;274(38):26917-26921.

23. Rosette C, Karin M. Ultraviolet light and osmotic stress: activation of the JNK cascade through multiple growth factor and cytokine receptors. Science. 1996;274(5290):1194-1197.

24. Coffer PJ, Burgering BM, Peppelenbosch MP, Bos JL, Kruijer W. UV activation of receptor tyrosine kinase activity. Oncogene. 1995; 11(3):561-569.

25. Pawson T, Scott JD. Signaling through scaffold, anchoring, and adaptor proteins. Science. 1997;278(5346):2075-2080.

26. Zheng CF, Guan KL. Properties of MEKs, the kinases that phosphorylate and activate the extracellular signal-regulated kinases. J Biol Chem. 1993;268(32):23933-23939.

27. Angel P, Karin M. The role of jun, fos and the AP-1 complex in cell-proliferation and transformation. Biochim Biophys Acta. 1991; 1072(2-3):129-157.

28. Chen CC, Mo FE, Lau LF. The angiogenic factor Cyr61 activates a genetic program for wound healing in human skin fibroblasts. $J$ Biol Chem. 2001;276(50):47329-47337.

29. Wu L, Levine AJ. Differential Regulation of the p21/WAF-1 and mdm2 Genes after High-Dose UV Irradiation: p53-Dependent and p53-Independent Regulation of the mdm2 Gene. Mol Med. 1997;3(7): 441-451.

30. Heck DE, Vetrano AM, Mariano TM, Laskin JD. UVB light stimulates production of reactive oxygen species: unexpected role for catalase. J Biol Chem. 2003;278(25):22432-22436.

31. Hanson KM, Clegg RM. Observation and quantification of ultravioletinduced reactive oxygen species in ex vivo human skin. Photochem Photobiol. 2002;76(1):57-63.

32. Sakurai H, Yasui H, Yamada Y, Nishimura H, Shigemoto M. Detection of reactive oxygen species in the skin of live mice and rats exposed to UVA light: a research review on chemiluminescence and trials for UVA protection. Photochem Photobiol Sci. 2005;4(9):715-720.

33. Ya'u J, Chindo BA, Yaro AH, Okhale SE, Anuka JA, Hussaini IM. Safety assessment of the standardized extract of Carissa edulis root bark in rats. J Ethnopharmacol. 2013;147(3):653-661.

34. Kokane DD, More RY, Kale MB, Nehete MN, Mehendale PC, Gadgoli $\mathrm{CH}$. Evaluation of wound healing activity of root of Mimosa pudica. J Ethnopharmacol. 2009;124(2):311-315. 
35. Bitiren M, Karakilcik AZ, Zerin M, et al. Protective effects of selenium and vitamin E combination on experimental colitis in blood plasma and colon of rats. Biol Trace Elem Res. 2010;136(1):87-95.

36. Gautam MK, Purohit V, Agarwal M, Singh A, Goel RK. In vivo healing potential of Aegle marmelos in excision, incision, and dead space wound models. ScientificWorldJournal. 2014;2014:740107.

37. Midwood KS, Orend G. The role of tenascin-C in tissue injury and tumorigenesis. J Cell Commun Signal. 2009;3(3-4):287-310.

38. Moyer KE, Saggers GC, Allison GM, Mackay DR, Ehrlich HP. Effects of interleukin-8 on granulation tissue maturation. J Cell Physiol. 2002; 193(2):173-179.
39. Huang C, Ma WY, Maxiner A, Sun Y, Dong Z. p38 kinase mediates UV-induced phosphorylation of 53 protein at serine 389 . J Biol Chem. 1999;274(18):12229-12235.

40. Bulavin DV, Saito S, Hollander MC, et al. Phosphorylation of human p53 by p38 kinase coordinates N-terminal phosphorylation and apoptosis in response to UV radiation. EMBO J. 1999;18(23):6845-6854.

\section{Publish your work in this journal}

Clinical Interventions in Aging is an international, peer-reviewed journal focusing on evidence-based reports on the value or lack thereof of treatments intended to prevent or delay the onset of maladaptive correlates of aging in human beings. This journal is indexed on PubMed Central, MedLine,
CAS, Scopus and the Elsevier Bibliographic databases. The manuscript management system is completely online and includes a very quick and fair peer-review system, which is all easy to use. Visit http://www.dovepress. com/testimonials.php to read real quotes from published authors. 